\title{
Association between Lung Function and Vocal Affections Arising from Tobacco Consumption
}

\author{
${ }^{1}$ Speech Language Pathologist by Universidade Federal de Ciências \\ da Saúde de Porto Alegre-UFCSPA. Mastering Post Graduate \\ Program in Rehabilitation Sciences - emphasis on Musculoskeletal \\ Rehabilitation - UFCSPA \\ ${ }^{2}$ Statistics with Masters in Business Administration-emphasis on \\ Marketing by the Universidade Federal do Rio Grande do Sul-UFRGS. \\ Is currently a professor of higher education institutions and ULBRA \\ UNISINOS \\ ${ }^{3}$ Speech Language Pathologist with Masters and Doctor in \\ Linguistics-PUCRS. Associate Professor, Department of Speech \\ Pathology, at Universidade Federal de Ciências da Saúde de Porto \\ Alegre-UFCSPA
}

Karoline Weber dos Santos ${ }^{1}$ Simone Soares Echeveste ${ }^{2}$ Deisi Cristina Gollo Marques Vidor ${ }^{3}$

\author{
Address for correspondence Karoline Weber dos Santos, Fga, \\ Universidade Federal de Ciências da Saúde de Porto Alegre, Rua José \\ Grimberg, 70, Porto Alegre/ Rio Grande do Sul, Brasil \\ (e-mail: karolweber@gmail.com).
}

Int Arch Otorhinolaryngol 2014;18:11-15.

\begin{abstract}
Introduction Smoking is a major risk factor for numerous diseases; it is necessary to analyze the impact that the habit can have on vocal health.

Objectives To determine the influence of smoking on changes in vocal production and lung vital capacity compared with nonsmokers.

Methods This cross-sectional study compared smokers and nonsmokers (24 subjects each). Each participant underwent a vocal and spirometric evaluation to measure vital lung capacity.

Results The results showed a worsening in lung vital capacity and other parameters of voice in smokers compared with nonsmokers. Furthermore, the decreased pulmonary vital capacity affected the evaluated voice parameters, and decreased carrying capacity

Keywords

- smoking

- vital capacity

- dysphonia

- voice quality

- voice disorders was closely related to smoking. The time and amount of consumption had a direct relationship with the vocal and maximum phonation time.

Conclusions This study showed that smoking causes voice disorders due to lung weakness. Thus, voice changes are affected both directly by interference of smoking on vocal structures and indirectly by increased weakness, which impairs lung vocal production.
\end{abstract}

\section{Introduction}

Smoking is considered by the World Health Organization to be the leading cause of preventable death in the world. However, smoking cessation is difficult, because the tobacco produces pleasurable sensations in the individual consuming it, even after a long period. Among the most common diseases in smokers are heart and breathing problems, such as heart failure and lung cancer. ${ }^{1,2}$
Within speech, vocal changes are most often described and most studied in relation to smoking, because the accumulation of toxic substances across the respiratory tract can lead to a change in conformation of the laryngeal tract, affecting primarily the vocal folds. ${ }^{2}$ This anatomical variation may lead to a modification of vocal production, thus generating a framework of dysphonia. ${ }^{3}$

Smoking causes tissue changes in the middle portion of the vocal folds, and keratinization occurs in the free edge of the received

July 16, 2013

accepted

August 11, 2013
DOI http://dx.doi.org/

10.1055/s-0033-1358586.

ISSN 1809-9777.
Copyright ( $\odot 2014$ by Thieme Publicações License terms Ltda, Rio de Janeiro, Brazil

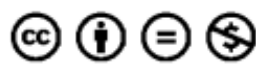


vocal fold tissue. ${ }^{3}$ Furthermore, smoking generates hyperplasia of basal cells and epithelial cells and causes congestion of blood vessels and inflammatory infiltration. ${ }^{4}$ This structural change has a negative impact on voice quality, modifying aspects of vocal pitch, by stiffening the free edge, making it thicker and causing noticeable hoarseness due to reduced mobility. ${ }^{5}$

Other problems commonly found in smokers occur in breathing. Once the carbon dioxide stiffens the respiratory epithelium, the ciliary function is impaired, thus reducing the absorption of air and reducing the ability to cleanse impurities from the external environment. ${ }^{1}$ This accumulation of impurities leaves the individual with a sense of continual tiredness, which, coupled with the modification of laryngeal structures, aggravates the dysphonia, because the respiratory effort creates tension in utterance. ${ }^{5}$ A properly functioning lung is no guarantee of long phonation time, because aspects of respiratory control and tension held in the issue directly influence this production. Nevertheless, it is known that the respiratory weakness is able to modify the vocal patterns, influencing the maintainability of vocal production. ${ }^{6}$

Given the vocal changes due to smoking, this study aims to characterize and verify the existence of a relationship between the key factors involved in vocal production, such as vital capacity (VC) and maximum phonation time, and markers of vocal quality in smokers and nonsmokers.

\section{Methods}

This study was composed of 48 subjects divided into two groups: current tobacco users and individuals who never smoked. The smoking group was composed of 24 individuals from the pulmonology clinic of Santa Casa de Porto Alegre. The group of nonsmokers was composed of volunteers. All participants signed an informed consent after explanation of the objectives and procedures of the study. This study was approved by the Ethics Committee in Research of the institution (3636/11).

Age was classified as 18 to 25,26 to 40,41 to 60 , and 61 years and older. In each track six individuals were evaluated, three females and three males in each study group. Thus, the average age of individuals evaluated in the group of nonsmokers was 42.16 and 40.75 years, respectively, for men and women, and in the group of smokers, the average for both sexes was 43.41 years.

The study included subjects who were within the established age groups, healthy and without diagnosis of neurodegenerative or systemic changes, and not on medication at the time of evaluation.

The evaluation consisted in the perceptual voice analysis by measurement of the maximum phonation of the vowel / a /. In addition, we also measured the VC of the study subjects, considering that the data obtained by this measurement is a key marker of lung function.

To assess vocal characteristics, sustained vowel / a / was recorded. Voice recordings were given to two judges and voice analysis experts who performed the perceptual analysis. The judges were blinded to patient and group. For this analysis, we used a protocol of measurement scale GRBASI, ${ }^{7}$ which assesses aspects of degree of vocal alteration $(G)$, rough $(R)$, breathiness (B), asthenia (A), strain (S), and instability (I) on a scale that assigns values to four possible answers: unchanged ( grade $=0$ ), mild (grade $=1$ ), moderate (grade $=2$ ), and severe (grade $=3$ ). Also the maximum phonation of the vowel issued obtained by recording time was taken into consideration.

The VC was evaluated using the spirometer dry Barness with nasal occlusion. The subjects were instructed to remain seated with their back straight and hold a maximum inspiration followed by a maximal expiration. Care was taken to keep the mouth of the pipe level with the mouth of the patient and to ensure light permeability of the cannula tube without folds. Based on the evaluation, function was evaluated as suitable or unsuitable, taking into consideration the relationship between an individual's height and volume of air exhaled in accordance with the parameters provided by the equipment.

The data collected were analyzed using descriptive statistics and the statistical tests: Fisher exact test for correlation of qualitative characteristics, Student $t$ test for comparison of means between groups, and Spearman correlation analysis to check the influence among the variables. Results were considered significant at a level of $5 \%$, and maximum statistical software used for data analysis was SPSS version $10.0 .^{8}$

\section{Results}

- Table 1 shows the results of the comparison between the study groups regarding aspects vocal quality and appropriateness of the VC. The Fisher exact test showed that the VC was predominantly suitable in nonsmokers, whereas all members of the group of smokers showed abnormalities. Regarding aspects vocals, smokers showed a statistically significant result for the parameters degree of change, roughness, vocal tension, and instability, with moderate outcome according to the scale used.

Spearman correlation analysis is reported in - Table $\mathbf{2}$ and shows an inverse association between VC with the vocal characteristics of the group of smokers: the lower the VC, the greater the degree of modification found. Conversely, this group presented a direct relationship between VC and maximum phonation time.

In - Table 3, we can see the average maximum phonation time of nonsmokers and smokers. The Student $t$ test found a significant difference in the variable between the study groups, with a significantly higher than average result for the nonsmokers.

The average time as a smoker was 22.41 years for the men and 24.58 years for the women. The average consumption was 24.75 and 15.16 cigarettes per day, respectively, for men and women. Thus, the results in -Table 4 show the relationship between duration of tobacco use and the amount of cigarettes smoked per day and the variables analyzed in the study. Regarding the length of cigarette smoking, Spearman correlation analysis found that this variable had a direct correlation with the degree of alteration, roughness, breathiness, vocal tension, and instability. Regarding the influence of daily 
cigarette consumption in these variables, there was a correlation with the degree of alteration, roughness, breathiness, and vocal instability. In addition, there was an inverse correlation between the time and the amount of cigarettes consumed in the maximum phonation time.

\section{Discussion}

The data presented show that smokers have on average a moderate change in vocal parameters, and nonsmokers do not have significant change, confirming the literature data. ${ }^{9}$ Smoking is a major risk factor for changes in the conformation of the vocal folds, producing mainly glottic edema. This edema decreases the fundamental frequency of the voice, making it more severe, with hoarse breaks, leaving it unstable and odd-sounding to listeners, who interpret this change as hoarseness. In addition, the incomplete closure of the larynx, due to edema in one or both vocal cords, usually occurs at the laryngeal tract due to constant exposure to heat, which increases tension during emission regions to compensate for performing incomplete glottal closure. ${ }^{10}$ Although excessive strain occurs during emission, some points of the glottis do not close completely, allowing the passage of air without sound, manifesting as breathiness during emission. Thus, the results presented in this study support the literature, because the smokers presented significant changes in relation to the group of nonsmokers regarding glottal tension, which contributes to increased glottal closure, offsetting the changed components described. Conversely, the same group showed no significant changes in asthenia, because opposing

Table 1 Comparison between the groups regarding VC and vocal aspects of qualitative

\begin{tabular}{|c|c|c|c|c|c|c|c|c|}
\hline \multirow[t]{3}{*}{ Variable } & \multirow[t]{3}{*}{ Category } & \multicolumn{4}{|c|}{ Group } & \multirow{2}{*}{\multicolumn{2}{|c|}{ Total }} & \multirow[t]{3}{*}{$p$} \\
\hline & & \multicolumn{2}{|c|}{ Nonsmoker } & \multicolumn{2}{|c|}{ Smoker } & & & \\
\hline & & $n$ & $\%$ & $n$ & $\%$ & $n$ & $\%$ & \\
\hline \multirow[t]{2}{*}{ VC } & Appropriate & 17 & 70.8 & - & - & 17 & 35.4 & $<0.001^{\mathrm{a}}$ \\
\hline & Inappropriate & 7 & 29.2 & 24 & 100.0 & 31 & 64.6 & \\
\hline \multirow[t]{4}{*}{ G } & No change & 6 & 25.0 & 1 & 4.2 & 7 & 14.6 & $0.015^{b}$ \\
\hline & Light & 11 & 45.8 & 6 & 25.0 & 17 & 35.4 & \\
\hline & Moderate & 7 & 29.2 & 15 & 62.5 & 22 & 45.8 & \\
\hline & Severe & - & - & 2 & 8.3 & 2 & 4.2 & \\
\hline \multirow[t]{4}{*}{$\mathrm{R}$} & No change & 7 & 29.2 & 1 & 4.2 & 8 & 16.7 & $0.022^{\mathrm{b}}$ \\
\hline & Light & 13 & 54.2 & 11 & 45.8 & 24 & 50.0 & \\
\hline & Moderate & 4 & 16.7 & 9 & 37.5 & 13 & 27.1 & \\
\hline & Severe & - & - & 3 & 12.5 & 3 & 6.3 & \\
\hline \multirow[t]{4}{*}{ B } & No change & 13 & 54.2 & 6 & 25.0 & 19 & 39.6 & $0.105^{c}$ \\
\hline & Light & 9 & 37.5 & 11 & 45.8 & 20 & 41.7 & \\
\hline & Moderate & 2 & 8.3 & 5 & 20.8 & 7 & 14.6 & \\
\hline & Severe & - & - & 2 & 8.3 & 2 & 4.2 & \\
\hline \multirow[t]{4}{*}{ A } & No change & 22 & 91.7 & 22 & 91.7 & 44 & 91.7 & $>0.999^{c}$ \\
\hline & Light & 2 & 8.3 & 2 & 8.3 & 4 & 8.3 & \\
\hline & Moderate & - & - & - & - & - & - & \\
\hline & Severe & - & - & - & - & - & - & \\
\hline \multirow[t]{4}{*}{$S$} & No change & 8 & 33.3 & 5 & 20.8 & 13 & 27.1 & $0.007^{a}$ \\
\hline & Light & 16 & 66.7 & 11 & 45.8 & 27 & 56.3 & \\
\hline & Moderate & - & - & 8 & 33.3 & 8 & 16.7 & \\
\hline & Severe & - & - & - & - & - & & \\
\hline \multirow[t]{4}{*}{1} & No change & 17 & 70.8 & 8 & 33.3 & 25 & 52.1 & $0.011^{\mathrm{b}}$ \\
\hline & Light & 7 & 29.2 & 12 & 50.0 & 19 & 39.6 & \\
\hline & Moderate & - & - & 4 & 16.7 & 4 & 8.3 & \\
\hline & Severe & - & - & - & - & - & - & \\
\hline
\end{tabular}

Abbreviations: A, asthenia; B, breathy; G, degree of change; I, instability; R, roughness; S, tension; VC, vital capacity.

${ }^{a} p \leq 0.01$.

${ }^{\mathrm{b}} p \leq 0.05$.

${ }^{\mathrm{C}}$ Not significant. 
Table 2 Influence of VC in voice quality and maximum phonation time

\begin{tabular}{|l|l|l|}
\hline \multirow{2}{*}{ Variable } & \multicolumn{2}{|c|}{ Correlation with CV } \\
\cline { 2 - 3 } & $\mathrm{R}$ & $\mathrm{P}$ \\
\hline $\mathrm{G}$ & -0.436 & $0.002^{\mathrm{a}}$ \\
\hline $\mathrm{R}$ & -0.362 & $0.011^{\mathrm{b}}$ \\
\hline $\mathrm{B}$ & -0.349 & $0.015^{\mathrm{b}}$ \\
\hline A & -0.145 & $0.326^{\mathrm{c}}$ \\
\hline S & -0.345 & $0.016^{\mathrm{b}}$ \\
\hline I & -0.510 & $<0.001^{\mathrm{a}}$ \\
\hline MPT / a / & 0.518 & $<0.001^{\mathrm{a}}$ \\
\hline
\end{tabular}

Abbreviations: A, asthenia; B, breathy; G, degree of change; I, instability MPT / a /, maximum phonation time of the vowel / a /; NS, not significant; $R$, roughness; $S$, tension; VC, vital capacity.

${ }^{\mathrm{a}} \mathrm{p} \leq 0.01$.

${ }^{\mathrm{b}} \mathrm{p} \leq 0.05$.

${ }^{\mathrm{c}}$ Not significant.

Table 3 Comparison of maximum phonation time of the study groups

\begin{tabular}{|l|l|l|l|l|}
\hline Group & $n$ & \multicolumn{2}{|c|}{ MPT / a / } & \multirow{2}{*}{$\begin{array}{l}\text { Standard } \\
\text { deviation }\end{array}$} \\
\cline { 3 - 4 } & & Average & 2.59 & $<0.001^{\text {a }}$ \\
\hline Nonsmoker & 24 & 13.00 & 2.83 & \\
\hline Smoker & 24 & 9.42 & 2 & \\
\hline
\end{tabular}

Abbreviation: MPT / a /, maximum phonation time of the vowel / a /. ${ }^{\mathrm{a}} \mathrm{p} \leq 0.01$.

Table 4 Influence of time and amount of tobacco consumed in voice quality and maximum phonation time

\begin{tabular}{|l|l|l|l|l|}
\hline \multirow{2}{*}{ Variable } & \multicolumn{2}{|c|}{ Smoking time } & \multicolumn{2}{c|}{$\begin{array}{l}\text { Cigarettes } \\
\text { smoked per day }\end{array}$} \\
\cline { 2 - 5 } & $\mathrm{r}$ & $\mathrm{P}$ & $\mathrm{r}$ & $\mathrm{P}$ \\
\hline $\mathrm{G}$ & 0.545 & $<0.001^{\mathrm{a}}$ & 0.440 & $0.002^{\mathrm{a}}$ \\
\hline $\mathrm{R}$ & 0.513 & $<0.001^{\mathrm{a}}$ & 0.475 & $0.001^{\mathrm{a}}$ \\
\hline $\mathrm{B}$ & 0.497 & $<0.001^{\mathrm{a}}$ & 0.267 & $0.066^{\mathrm{c}}$ \\
\hline $\mathrm{A}$ & 0.093 & $0.529(\mathrm{NS})$ & 0.003 & $0.984^{\mathrm{c}}$ \\
\hline $\mathrm{S}$ & 0.390 & $0.006^{\mathrm{a}}$ & 0.353 & $0.014^{\mathrm{b}}$ \\
\hline I & 0.521 & $<0.001^{\mathrm{a}}$ & 0.399 & $0.005^{\mathrm{a}}$ \\
\hline $\mathrm{MPT} / \mathrm{a} /$ & -0.693 & $<0.001^{\mathrm{a}}$ & -0.459 & $0.001^{\mathrm{a}}$ \\
\hline
\end{tabular}

Abbreviations: A, asthenia, B, breathy, G, degree of change; I, instability; MPT / a /, maximum phonation time of the vowel / a /; NS, not significant; $\mathrm{R}$, roughness; $\mathrm{S}$, tension.

${ }^{\mathrm{a}} \mathrm{p} \leq 0.01$.

${ }^{\mathrm{b}} \mathrm{p} \leq 0.05$

${ }^{c}$ Not significant. mechanisms are performed in which asthenia is characterized by fatigue and inability to support the voice during glottal closure. ${ }^{9,11}$

Weak lung function has an inverse association with vocal parameters and directs the maximum phonation time in the smokers, according to data presented in - Table 2. Thus, in addition to changes in the laryngeal tract due to heat and exposure to harmful agents and decreased lung capacity, which reduces the amount of air available at each respiratory cycle, the strain will increase during the emission vocal, further damaging the quality of voice. Thus, the vocal parameters have changed two aspects that strongly influence the quality of voice production: anatomical and functional changes of the larynx and lung weakness, manifested by reduced VC. ${ }^{12}$

Smoking is a major cause of chronic obstructive pulmonary disease (COPD), which decreases the VC of smokers compared with nonsmokers. ${ }^{13}$ Literature data show an average $70 \%$ difference between the changes in ratios in VC between smokers and nonsmokers, which corroborates the findings of this study. ${ }^{14}$ This weakness is due to the buildup of toxic substances in the respiratory tract, decreasing the antioxidant capacity of cellular protection, exposing the tissue to harmful agents, and decreasing its functionality. This weakness occurs due to the simultaneous presence of oxidative stress in tissues, which can lead to increased amounts of mucus and the possibility of bronchoconstriction and an increased number of repair cells, causing functional impairment. ${ }^{15}$ In addition, there is a decrease in the inflammatory response of the lung tissues that are exposed to conditions that cause permanent debility, as well as COPD. ${ }^{13}$

Another aspect to be considered is the significant decrease of the maximum times of utterance of smokers compared with nonsmokers. Corroborating the findings of this study, the literature shows that there is a close relationship between VC and maximum phonation time. Nevertheless, an adequate lung function is not enough to ensure longer phonation time, because other aspects also affect this ratio. Thus, in general, it is expected that because the VC is changed, the maximum speech time will also be reduced. Adequate lung function will favor the utterance throughout expiration, extending maximum phonation time, depending on other aspects, such as expiratory control of the individual. ${ }^{6}$ Because smoking reduces lung function and the functional air volume, the maximum phonation time as well as the carrying capacity of the connected speech may be reduced when compared with individuals without weakness, ${ }^{13}$ as the evidence shows in - Table 3. So even if there was proper vocal control, lung weakness stands out as a factor that can considerably hamper the issuance, reducing the ability to support the voice and causing compensatory mechanisms that increase the change of vocal markers and show a picture of functional organic dysphonia.

Individuals in this study present time and average consumption amount similar to those described in the literature, with habits started around 20 years of age and a mean daily consumption of two packs per day. ${ }^{16}$ Time and the amount of 
cigarettes consumed are directly related to increased lung and worsening weakness in vocal production. The greater the amount consumed and the longer time as a smoker, the smaller the time of voice production, because these factors result in decreased lung capacity with a consequent reduction in the utterance ${ }^{17}$ according to the findings shown in -Table 4. This relationship is rarely described in the literature, but in fact, it is not just a spurious correlation presented in this work, as it has been effectively observed along with a degeneration of the upper main vocal parameters assessed in individuals with a long history and a large amount of tobacco. Furthermore, the strain is a vocal marker associated with the time as a smoker and may be closely related to the factors described above, with one marker present due to the weakness of the sum of lung function over the years and modification of the laryngeal tissues involved in voice production.

\section{Conclusion}

Despite the limited sample size of the study, the data obtained showed the correlation between smoking and diseases of vocal production and showed the habit to be a major risk factor for decreased vocal production. Also, the influence of time and amount of tobacco consumed and lung weakness were shown. Few works in the literature show these correlations. Further work should be performed to confirm these findings.

\section{References}

1 Tabaco e Tabaquistas. ArqMed 2007;21(5-6):183-193

2 Duarte JL, Faria FC, Ceolin DS, Cestari TM, Assis GF. Efeitos da inalação passiva da fumaça de cigarro sobre as pregas vocais de ratos. Rev Bras Otorrinolaringol 2006;72(2):210-216

3 Cielo CA et al. Hábitos de tabagismo e etilismo em disfonias. Rev Cien Med Bio 2010;9(2):119-125

4 de Oliveira Semenzati G, de Souza Salgado B, Rocha NS, Michelin Matheus SM, de Carvalho LR, Garcia Martins RH. Histological and immunohistochemical study of the expression of p53 and ki-67 proteins in the mucosa of the tongue, pharynx and larynx of rats exposed to cigarette smoke. Inhal Toxicol 2012;24(11): 723-731

5 Wan P, Huang Z. [The effect of smoke and alcohol abuse to voice]. Lin Chung Er Bi Yan Hou Tou Jing Wai Ke Za Zhi 2008;22(15): 686-687

6 Miglioranzi SL. Capacidade vital e tempos máximos de fonação de /e/ áfono e /s/ em mulheres adultas [thesis]. Santa Maria: Universidade Federal de Santa Maria; 2010

7 Hirano M. Clinical Examination of Voice. New York, NY: Springer Verlag; 1981:81-84

8 Callegari-Jacques SM. Testes não-paramétricos. In: CallegariJacques SM, ed. Bioestatística: Princípios e Aplicações. 1st Ed. São Paulo, Brasil: Artmed; 2003:165-184

9 Cielo CA, Finger LS, Rosa JC, Brancalioni AN. Lesões organofuncionais do tipo nódulos, pólipos e edema de reinke. Rev CEFAC 2011; 13(4):735-748

10 Behlau MS, Gama ACC. Estudo da constância de medidas acústicas de vogais prolongadas e consecutivas em mulheres sem queixa de voz e em mulheres com disfonia. Rev Soc Bras Fonoaudiol 2009; 14(1):8-14

11 Vasconcelos SV, Mello RJV, Silva HJS. Efeitos do envelhecimento e do fumo nas pregas vocais: uma revisão sistemática. ACTA ORL Técnicas em Otorrinolaringologia 2009;27(1):9-14

12 Cielo CA, Gonçalves BFT, Lima JP, Christmann MK. Afecções laríngeas, tempos máximos de fonação e capacidade vital em mulheres com disfonia organofuncional. Rev CEFAC 2012;14(3): 481-488

13 Nunes E. Consumo de tabaco. . Efeitos na saúde. Rev Port ClinGeral 2006;22:225-244

14 Arabaci U, Akdur H, Yiğit Z. Effects of smoking on pulmonary functions and arterial blood gases following coronary artery surgery in Turkish patients. Jpn Heart J 2003;44(1):61-72

15 Rufino R, Lapa e Silva JR. Cellular and biochemical bases of chronic obstructive pulmonary disease. J Bras Pneumol 2006;32(3): 241-248

16 Costa JS, Silveira MF, Gazalle FK, et al. Consumo abusivo de álcool e fatores associados: estudo de base populacional. Rev Saude Publica 2004;38(2):284-291

17 Fiqueiredo DC, Souza PRF, Gonçalves MI, Biase NG. Análise perceptivo-auditiva, acústica computadorizada e laringológica da voz de adultos jovens fumantes e não-fumantes. Rev Bras Otorrinolaringol (Engl Ed) 2003;69(6):791-799 